\title{
The Correlation between the Intrinsic and Extrinsic Molecular Markers in the Inhibition of the Lungs Carcinogenesis Growth by Mahkota Dewa Polyphenols on Balb/c Mouse
}

\author{
Theopilus Watuguly ${ }^{1 *}$, Kustarini Samsuria Indranila ${ }^{2}$, Suharyo Hadisaputro ${ }^{3}$, Edi Dharmana ${ }^{4}$, \\ Lyle E. Craker5
}

\author{
${ }^{1}$ Biologi Program, Department of Mathematic \& Natural Science, University of Pattimura, Ambon, Indonesia \\ ${ }^{2}$ Department of Clinical Pathology, University of Diponegoro, Semarang, Indonesia \\ ${ }^{3}$ Departement of Internal Medicine, University of Diponegoro, Semarang, Indonesia \\ ${ }^{4}$ Departement of Imunology dan Parasitology, University of Diponegoro, Semarang, Indonesia \\ ${ }^{5}$ Department of Plant, Soil \& Insect Sciences, University of Massachusetts, Amherst, USA \\ Email: *twatuguly@gmail.com
}

How to cite this paper: Watuguly, T., Indranila, K.S., Hadisaputro, S., Dharmana, E. and Craker, L.E. (2020) The Correlation between the Intrinsic and Extrinsic Molecular Markers in the Inhibition of the Lungs Carcinogenesis Growth by Mahkota Dewa Polyphenols on Balb/c Mouse. Open Journal of Applied Sciences, 10, 271-286. https://doi.org/10.4236/ojapps.2020.106021

Received: April 30, 2020

Accepted: May 30, 2020

Published: June 2, 2020

Copyright $\odot 2020$ by author(s) and Scientific Research Publishing Inc. This work is licensed under the Creative Commons Attribution International License (CC BY 4.0).

http://creativecommons.org/licenses/by/4.0/ (c) (i) Open Access

\begin{abstract}
Phytochemical analysis shows that mahkota dewa fruit contains polyphenols. Mahkota dewa polyphenols have the ability to disrupt or reverse the stages of cancer or a carcinogenesis process by affecting the intracellular signaling tissue molecules involved in an initiation and/or promotion. This chemopreventive potential is highly anticipating. The use, effectiveness, and benefits of the polyphenol have been empirically and pre-clinically proved without side effects. A multivariate analysis using Spearman's test was conducted to examine the correlation between variables. Meanwhile, to determine which dependent variables played the strong role, a discriminant function analysis was performed with a significance level of $\mathrm{p}<0.05$ and a reliability level of $95 \%$. The results showed that the mahkota dewa polyphenols acted as the suppressor agent by inducing apoptosis. This finding proved that polyphenols addition might result in death signal transduction through an apoptosis pathway which is either mediated by death receptor or mitochondria. The results of this study indicate that there is a relationship between apoptotic cell death mediated by death receptor and mitochondria through the administration of mahkota dewa polyphenols, it can be argued that mahkota dewa polyphenols can function in lung cancer chemoprevention in mice strain Balb/c.
\end{abstract}

\section{Keywords}

Polyphenols, Lungs Carcinogenesis, Molecular Markers, p53, Bcl-2, Bax, 


\section{Introduction}

The mechanism of apoptosis through the mitochondrial (intrinsic) pathway is initiated by the activation of tumor protein compressor 53, an important regulator mediated by mitochondria in response to cellular stress (Breuer et al. [1]). Protein 53 can increase proapoptotic protein (Bax, Bad, Bid, PUMA, Apaf-1) and/or decrease antiapoptotic protein (Bcl-2, Bcl-xL) (Hanahan and Weinberg [2]) in response to DNA damage (Vousden and $\mathrm{Lu}$ [3]) which spurred the release of cytochrome $\mathrm{c}$ from mitochondria (Fisher [4]). The cytochrome $\mathrm{c}$ release process will activate a number of caspases resulting in apoptosis (Sareen et al. [5], (Zimmermann et al. [6]).

While the mechanism of cell death through the death receptor pathway (extrinsic) is triggered through death activators that bind to the receptors on the cell surface concerned such as Tumor Necrosis Factor (TNF) and Ligand Fas (FasL) (Hanahan and Weinberg [2]). The Fas ligand pulls the Fas-associated death domain (FADD) in the intracellular direction which then captures procaspase- 8 (Pop et al. [7], Viktorsson and Lewensohn [8]). Procaspase-8 transactivation will break down and active caspase- 8 then activate procaspase- 3 directly and activate active caspase- 3 so that apoptosis occurs or enlarge the signal through splitting Bids (Garrido et al. [9]. According to Owen-Schaub, et al. [10], in addition to protein 53 it can activate the mitochondrial pathway, it can also activate the receptor death pathway so that it can activate caspase-8.

The process of apoptosis is important in eliminating cells that have damaged DNA that cannot be repaired and if the ability of apoptosis is decreased (Sreedhar and Csermely [11]) or the dysregulation of apoptosis results in cells surviving with DNA damage which in turn results in mutations 4 and is an important process in carcinogenesis (Crighton and Ryan [12], Rousselot and Garnero [13]). Apoptosis is an important event in the regulation of carcinogenesis and an appropriate balance between cell proliferation and cell death (apoptosis) determines the emergence of malignant neoplasia, hence both cellular processes are targets for chemopreventive intervention (Banerjee et al. [14]). For this reason, testing of medicinal plants as a chemopreventive agent capable of programmatically inducing cancer cell death by providing minimum side effects is indispensable in chemopreventive (Kintono and Pihie [15]).

Chemopreventive strategies aim at cancer intervention by administering natural ingredients that can inhibit, delay, and block or restore the process of carcinogenesis, which can be used to protect against carcinogenic exposure and reduce the risk of lung cancer (Banerjee et al. [16]). Many potential chemopreventive polyphenols can disrupt or reverse the carcinogenesis process by acting on intracellular signaling tissue molecules involved in initiation and/or promotion, 
but phenolic compounds can also stop or reverse the stage of cancer development (Manson [17], Surh [18]). Its use, effectiveness and utilization have been proven without side effects both empirically and pre-clinical testing (Soeksmanto [19], Soeksmanto [20]).

Polyphenols are a very large general chemical class with $>8000$ known components (Finley [21]; Ross and Kasum [22]). Although the hidrophobic nature is found in most phenolic groups, glycoliation by sugars such as glucose, rhamnosa, galactose and arabinosa makes it soluble in water (Scalbert et al. [23]; Giovannelli et al. [24]). Based on phytochemical analysis, polyphenols are one of the compounds found in mahkota dewa plant (Lisdawati [25], Watuguly [26], Watuguly [27], Faried et al. [28], Sutiono et al. [29], Shahrzad and Bitsch [30]). In vitro test results conducted by Budijitno et al. [31] by looking at the anticancer effects of breast on $\mathrm{C} 3 \mathrm{H}$ mice, were able to increase perforin expression and apoptotic index. Mahkota dewa polyphenols also appeared to have significant efficacy in increasing the apoptosis index.

Experimental studies conducted by Faried et al. [28] in vitro and in vivo on mahkota dewa extracts by looking at anticancer activity in human esophageal squamous cell carcinoma, are able to induce apoptosis in human esophageal cell tissue. In addition, the in vitro test of anticancer activity in $\mathrm{C} 3 \mathrm{H}$ mice was able to increase apoptosis by using ethanol extracts mahkota dewa flesh 80 times the human dose induced by transplantation (Rahmawati et al. [32]). The results of other experiments carried out, showed that the mahkota dewa fruit of young and old had hypoglycemic activity with in vitro experiments with increased enzymes of alfaglucosidation and in vivo in mice (Sugiwati et al. [33]).

Mahkota dewa polyphenols are natural phenolics which are expected to have antioxidant properties and can potentially inhibit the growth of lung cancer cells. Studies by Frei and Higdon [34] show that polyphenols act as antioxidants and play a role in preventing cancer. As an antioxidant and anticancer, mahkota dewa polyphenols are expected to induce apoptosis in both the mitochondrial pathway and the death receptor pathway (Giovannini et al. [35]). The purpose of this study is to prove that mahkota dewa polyphenols can inhibit pulmonary carcinogenesis through molecular marker interactions in the intrinsic pathway and extrinsic pathway in Balb/c strain mice.

\section{Materials and Methods}

\subsection{Study Area}

The study began in February 2010-February 2011. The process of taking research material mahkota dewa plant (Phaleria macrocarpa [Scheff.] Boerl.) Was obtained from Ambon-Maluku, Indonesia. The process of plant determination is carried out at the Bogoriense Herbarium, Bogor, and West Java. Experimental animal research was carried out at the Integrated Research and Development Laboratory Unit IV, Experimental Animal Development Division of Gajah Mada University LPPT Unit IV-UGM, while extraction and fractionation were carried 
out at LPPT Unit I. Fundamental considerations on the use of LPPT-UGM, because they had obtained KAN certification and ISO 9001-9002.

While the manufacture of paraffin blocks to immunohytochemistry and the reading of preparations were carried out at the Anatomical Pathology Laboratory of the Faculty of Medicine, Diponegoro University, Semarang, the Anatomical Pathology Laboratory, Yogyakarta Yogyakarta and the Anatomical Pathology Laboratory Dr. Sardjito Yogjakarta.

\subsection{Design and Study Variables}

This study is a pure in-laboratory experimental research with posttest control group design, using experimental animal mice Balb/c strains as research objects (Portney et al. [36], Gross and Mary [37], Campbell [38]). Independent Variable: in this study were polyphenols from the extract of the mahkota dewa fruit. Dependent Variables: in this study relating to apoptosis include: p53 expression, Bcl-2 and Bax expression, caspase-3, caspase- 8 and caspase-9. Controlled Variables: strain, age, sex of test animals strain Balb/c. All animals are kept, handled and sacrificed according to the guidelines of the Health Research Ethics Commission (CEHR), Faculty of Medicine, Diponegoro University and Dr. Central Hospital Kariadi Semarang-Indonesia.

\subsection{Research Samples}

The number of samples used in the current research was determined based on the minimal number of samples used in a common experimental study which was $(t-1)(n-1) \geq 15$. The result of the calculation using the formula suggested five mice as the minimum number to be used in each treatment. One treatment group consisted of three terminated periods. Every terminated period employed 5 mice. This research, therefore, used $45 \mathrm{Balb} / \mathrm{c}$ mice in total. This figure had exceeded the criteria set by WHO for mutagenicity ( 5 animals).

\subsection{IHC Staining}

IHC painting uses antibodies labeled by the enzyme horseradish peroxidase. These antibodies will be bound to specific proteins. In cells that express proteins positively, the enzymes labeled in antibodies react with chromogen DAB to become a brown substrate, whereas cells with negative expressions will appear purple.

Immunohistochemical staining is scored according to the number of positively colored cells per 100 counted cells. Protein immunoreactivity 53, bax, Bcl-2, caspase- 3 , caspase- 8 and caspase- 9 are considered negative (0) when there is no staining; weak (1) when coloring is focal and rather intense; moderate/moderate (2) when about two-thirds of the cells are sufficiently colored; strong (3) when the majority of cells (>two thirds) are stained intensely. This inspection procedure is in accordance with that carried out by Mohan, et al. [39], Letchoumy et al. [40]. 


\subsection{Statistical Analysis}

Data on the expression of p53, protein Bax, protein Bcl-2, caspase-8, caspase- 9 and caspase- 3 proteins was collected in the form of ratio scales. Spearman's test was performed to test the correlation of the research variables. Meanwhile, to analyze which dependent variables played a strong role, a discriminant function analysis was conducted with a significance level of $\mathrm{p}<0.05$ and a reliability interval of 95\%. Data collected statistically was analyzed using SPSS vers. 19.

\section{Results}

\subsection{Histopathology of Lungs Carcinogenesis}

Findings of this research confirmed that the administration of polyphenols extracted from the mahkota dewa plants could induce apoptosis during lungs carcinogenesis. Therefore, next step to be taken was to determine the effects of the polyphenols on genes expression related to apoptosis. Studies have suggested that pro and anti-apoptosis proteins play a significant role in an apoptotic process; thus, the current study aimed to investigate the effects of the mahkota dewa polyphenols on the expression of $\mathrm{p} 53$, pro-apoptosis Bax and anti-apoptosis Bcl-2, Caspase-3, -8 and -9 proteins in Balb/c mice. Observations were conducted thoroughly by calculating the number of cells that positively expressed p53, Bax, Caspase-8, Caspase- 9 and Caspas 3 proteins (brown colored) and the number of cells that expressed Bcl-2 (purplish blue) on the bronchial epithelium with MoAb anti-proteins staining.

The role of the mahkota dewa polyphenols in Bax protein expression was examined with an immunohistochemical analysis which had a purpose to evaluate a histopathological observation. The result of the observation on p53 protein expression suggested an increase in every group of the proteins. This finding showed that compared to the carcinogenic control group, the experimental group had more positive cells that could be found in the bronchial areas. An increase in the caspase-8, -9 and caspase-3 proteins expression was also reported by the experimental group However, the results of the observations on Bax and Bcl-2 proteins expressions in the experimental group indicated a decrease.

Observation using a microscope in 5 visual fields with a magnification of $400 \times$. This observation starts from the left, right, upper, lower, and middle corners of the rat lung histology preparations. Each field of view was observed and a count was made of the number of cells. Results in pulmonary histopathology preparations on pulmonary features by H\&E staining. The histopathology of lungs carcinogenesis was depicted in Figure 1.

There was an increase reported by expressions of p53, Bax, Bcl-2, caspase-8, caspase-9, caspase-3 proteins as well for both the control and experimental group on week 8 , week, 17 , and week 26 . In the experimental group in particular, p53, Bax, caspase-8, caspase-9, and caspase-3 proteins expressions experienced an increase meanwhile Bcl-2 protein expression declined significantly (Table 1). 


\subsection{Multivariate Analysis Using Spearman's Correlation Test to Testing the Relationship between the Research Variables}

Findings of the research suggested that the mahkota dewa polyphenols could inhibit lungs carcinogenesis on the experimental animals. This phenomenon could be a result of the dependency of the research variables tested in this research which were related to either cell proliferation or apoptosis. Therefore, Spearman's correlation test was conducted to examine the relationship between all dependent variables observed in the current research.

The result of the normality test indicated that all data distributed normally; thus, it was necessary to conduct data transformation analysis (log_10) of which results showed that data distribution was not normal. Spearman's correlation test was therefore performed and the result indicated the level $(\mathrm{r}=0.00-0.199$ (very weak); $r=0.20$ - 0.399 (weak); $r=0.40-0.599$ (medium); $r=0.60-0.799$ (strong), and $\mathrm{r}=0.80-1.000$ (very strong) and direction of correlation between variables (positive $(+)$ or negative $(-)$ (see Table 2 ).

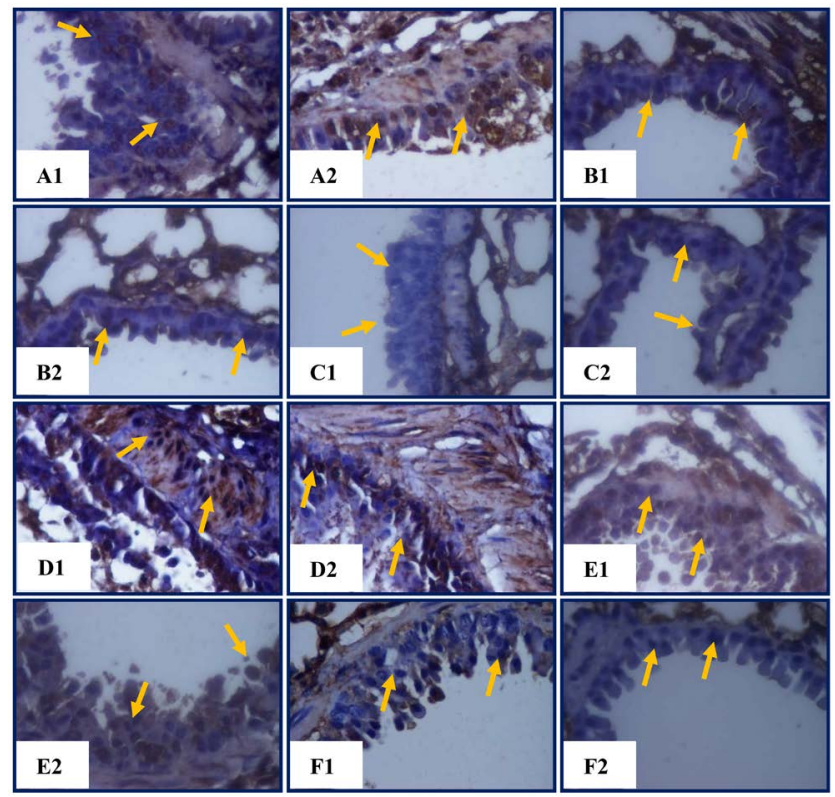

Figure 1. Histopathology in Balb/c Strain Mice. (A) The brown color of the cell nucleus shows the expression of protein 53 (Control $=\mathrm{A} 1$ and Treatment $=\mathrm{A} 2)$. The nucleus of the cell appears brown oval. (B) The brown color of the cytoplasm shows Bax protein expression (Control $=\mathrm{B} 1$ and Treatment $=\mathrm{B} 2$ ). The nucleus of the cell looks round and oval brown (black arrow). (C) The brown color of the cytoplasm shows the expression of $\mathrm{Bcl}-2$ protein (Control $=\mathrm{C} 1$ and Treatment $=\mathrm{C} 2$ ). The nucleus of the cell looks rounded oval blue-purple. (D) The brown color of the cytoplasm shows the expression of caspase- 8 (Control $=\mathrm{D} 1$ and Treatment $=\mathrm{D} 2)$. The nucleus of the cell looks round and oval brown (black arrow). (E) The brown color of the cytoplasm shows the expression of caspase-9 (Control = E1 and Treatment = E2). The core of the cell looks round oval blue-purple (black arrow). (F) Brown color in the cytoplasm shows the expression of caspase-3 (Control $=$ F1 and Treatment $=$ F2). The nucleus of the cell looks streaked with brown color. Observation of all cells with $400 \times$ magnification (histopathological pictures were taken based on permission from Watuguly TW, et al. [41] [42] [43] [44], Indranila KS, et al. [45]. 
Table 1. Description of the variable values changes in bronchial epithelium, apoptotic proteins of the control and experimental groups (mean $\pm \mathrm{SD}$ ).

\begin{tabular}{|c|c|c|c|c|c|c|}
\hline \multirow{2}{*}{ No. } & \multirow{2}{*}{$\begin{array}{l}\text { Group Variable } \\
\text { C \& T }\end{array}$} & \multirow{2}{*}{$\mathrm{N} / \mathrm{n}$} & \multicolumn{3}{|c|}{ Surgery Week } & \multirow[t]{2}{*}{$\mathbf{P}$} \\
\hline & & & 8 & 17 & 26 & \\
\hline \multirow{3}{*}{1.} & P53 & \multirow{4}{*}{$15 / 5$} & & & & \multirow{3}{*}{0.000} \\
\hline & - Control & & $1.84 \pm 0.29$ & $2.32 \pm 0.17$ & $2.28 \pm 0.33$ & \\
\hline & - Treatment & & $3.72 \pm 0.22$ & $5.20 \pm 0.14$ & $8.28 \pm 0.33$ & \\
\hline \multirow{3}{*}{2.} & Bax & & & & & \\
\hline & - Control & \multirow{2}{*}{$15 / 5$} & $4.04 \pm 0.21$ & $1.92 \pm 0.17$ & $1.92 \pm 0.10$ & \multirow{2}{*}{0.000} \\
\hline & - Treatment & & $5.96 \pm 0.32$ & $4.28 \pm 0.30$ & $4.68 \pm 0.22$ & \\
\hline \multirow{3}{*}{3.} & Bcl-2 & \multirow{4}{*}{$15 / 5$} & & & & \multirow{3}{*}{0.000} \\
\hline & - Control & & $5.80 \pm 0.31$ & $7.68 \pm 0.43$ & $9.64 \pm 0.26$ & \\
\hline & - Treatment & & $5.12 \pm 0.22$ & $4.84 \pm 0.08$ & $7.36 \pm 0.21$ & \\
\hline \multirow{3}{*}{4.} & Caspase-8 & & & & & \\
\hline & - Control & \multirow{2}{*}{$15 / 5$} & $0.32 \pm 0.10$ & $0.36 \pm 0.08$ & $0.72 \pm 0.30$ & \multirow{2}{*}{0.000} \\
\hline & - Treatment & & $0.64 \pm 0.16$ & $0.92 \pm 0.22$ & $2.04 \pm 1.05$ & \\
\hline \multirow{3}{*}{5.} & Caspase-9 & \multirow{4}{*}{$15 / 5$} & & & & \multirow{3}{*}{0.000} \\
\hline & - Control & & $0.32 \pm 0.10$ & $0.48 \pm 0.22$ & $0.28 \pm 0.10$ & \\
\hline & - Treatment & & $0.56 \pm 0.16$ & $1.00 \pm 0.20$ & $2.60 \pm 0.28$ & \\
\hline \multirow{3}{*}{6.} & Caspase-3 & & & & & \\
\hline & - Control & \multirow{2}{*}{$15 / 5$} & $0.28 \pm 0.17$ & $0.20 \pm 0.14$ & $0.56 \pm 0.16$ & \multirow{2}{*}{0.000} \\
\hline & - Treatment & & $0.60 \pm 0.14$ & $0.96 \pm 0.16$ & $2.52 \pm 0.33$ & \\
\hline
\end{tabular}

Note: $\mathrm{p}$ value $<0.05$. Kruskal Wallis Test.

Table 2. The results of the spearman's correlation test.

\begin{tabular}{|c|c|c|c|c|c|c|c|}
\hline \multicolumn{8}{|c|}{ Correlations } \\
\hline Variable & P53 & Bax & Bcl-2 & Cas-8 & Cas-9 & Cas-3 & IA \\
\hline \multirow[t]{2}{*}{ P53 } & 1 & $0.570^{* *}$ & -0.313 & $0.696^{* *}$ & $0.798^{* *}$ & $0.829^{* *}$ & $0.876^{* *}$ \\
\hline & . & 0.001 & 0.092 & 0.000 & 0.000 & 0.000 & 0.000 \\
\hline \multirow[t]{2}{*}{ Bax } & & 1 & $-0.621^{* *}$ & $0.379^{*}$ & $0.505^{* *}$ & $0.687^{* *}$ & $0.602^{* *}$ \\
\hline & & . & 0.000 & 0.039 & 0.004 & 0.000 & 0.000 \\
\hline \multirow[t]{2}{*}{ Bcl-2 } & & & 1 & -0.072 & -0.348 & $-0.462^{*}$ & -0.328 \\
\hline & & & . & 0.705 & 0.060 & 0.010 & 0.077 \\
\hline \multirow[t]{2}{*}{ Caspase- 8} & & & & 1 & $0.648^{* *}$ & $0.715^{* *}$ & $0.744^{* *}$ \\
\hline & & & & . & 0.000 & 0.000 & 0.000 \\
\hline \multirow[t]{2}{*}{ Caspase-9 } & & & & & 1 & $0.864^{* *}$ & $0.729^{* *}$ \\
\hline & & & & & . & 0.000 & 0.000 \\
\hline \multirow[t]{2}{*}{ Caspase-3 } & & & & & & 1 & $0.830^{* *}$ \\
\hline & & & & & & r & 0.000 \\
\hline
\end{tabular}

The results of the correlation test on Bax, Bcl-2, Cas- $8,-9,-3$ proteins were (0.006; $0.000 ; 0.000=$ significant); 0,191 (not significant); (0.017; 0.000 and 0.002 $=$ significant $)$. Each of the variables reported Spearman's correlation index as $(\mathrm{r}$ $=-0.488 ;-0.624=$ negative; medium and strong $) ;(r=0.754=$ positive; strong $) ;$ $(\mathrm{r}=-0.245 ;-0.433 ;-0.605 ;-0.533=$ negative; weak, medium, strong and medium). The results of the correlation test on p53 and Bax, Bcl-2, Cas-8, -9, -3 
proteins were $(0.001=$ significant $) ; 0.092$ (not significant); $(0.000 ; 0.000 ; 0.000$; $0.000=$ significant). Each of the variables reported Spearman's correlation index consecutively as $(\mathrm{r}=0.570=$ positive; medium $) ;(\mathrm{r}=-0.313=$ negative; weak $) ;(\mathrm{r}$ $=0.696 ; 0.798 ; 0.829 ; 0.876=$ positive; strong, strong, very strong, and very strong).

The results of the correlation test on Bax and Bcl-2, Cas-8, -9, -3 (0.000; 0.039; $0.004 ; 0.000 ; 0.000=$ Significant). Each of the variables reported Spearman's correlation index consecutively as $(\mathrm{r}=-0.621=$ negative; strong $) ;(\mathrm{r}=0.379$; $0.505 ; 0.687$ and 0.602 = positive; weak, medium, strong, and strong). The results of the correlation test on Bcl-2 and Cas- $8,-9,-3$ were $(0.705 ; 0.060=$ not significant $) ;(0.010=$ significant $) ;(0.077=$ not significant $)$. Each of the variables reported Spearman's correlation index consecutively as $(\mathrm{r}=-0.072 ;-0.348$; $-0.462 ;-0.328$ = negative; very weak, weak, medium, and weak).

The results of the correlation test on Cas- 8 and $-9,-3$ proteins. Each of the variables reported Spearman's correlation index consecutively as $(r=0.648 ; 0.715$ and 0.744 = positive; strong). The results of the correlation test on Cas-9 and Cas-3 proteins were significant $(0.000)$. Each of the variables reported Spearman's correlation index consecutively as $(r=0.864$ and $0.729=$ positive; very strong and strong).

\subsection{Discriminant Factors of the Research Variables}

Multivariate and discriminant analysis could be performed on data which distributed normally. Otherwise, a normality test should be conducted. The initial analysis indicated 2 outlier variables; therefore, data transformation was necessary. The result of the data transformation analysis suggested that all variables were homogeneous and distributed normally. As a result, a discriminant function analysis could be conducted. This analysis was preceded by an equality test to ensure that all independent variables and covariance groups were equal.

The discriminant function analysis was conducted to investigate the interaction roles and contribution of dependent variables observed in both groups (control and experimental groups). The present research employed stepwise discriminant analysis where the variables were inserted one by one into the discriminant model. Meanwhile, the final analysis showed that six variables (p53, Bax, Bcl-2, caspase-8, and -3) could be processed for further analysis, the Fisher's linear discriminant functions analysis (see Table 3 ).

Table 3 and Figure 2 presented values of each variable in the control and experimental groups which had been selected to proceed in the final analysis. To test, the accuracy of the discriminant functions classification, a cross-validated group test was conducted as shown in Table 4.

The results of the discriminant functions analysis indicated two cases, original group $(5 / 5 \times 100 \%=100 \%)$ and cross validated group $(5 / 5 \times 100 \%=100 \%)$. It can be concluded that both groups had the same functions. Output data in Table 5.14 presented that the accuracy of the model was $100.0 \%$ which suggested the 
inhibition of the lungs carcinogenesis. To anticipate bias, leave-one-out-cross validation was performed and the result was $100.0 \%$. It was then proved that the discriminant functions were very accurate. The original group variables included p53, Bax, Bcl-2, caspase-8, 9, and 3, meanwhile the cross validated group consisted of p53, Bax, Bcl-2, Cas-8 and -3. The results of the analysis, thus, indicated that caspase- 9 could be excluded from the analysis because this variable had the most less intense interaction with p53, Bax, Bcl-2 and caspase- 8 and -3 both in the control and experimental groups.

\section{Discussion}

The chemopreventive properties of the mahkota dewa polyphenols are assumed to be able to cause an apoptotic process indicated by cell's blebbing and shrinkage, increased permeability and decreased mitochondrial potential. An apoptotic cell will experience DNA damage which can be detected with TUNEL staining. According to Bonner et al. [46], the use of this method can result in high specificity to detect cells that undergo an apoptotic process.

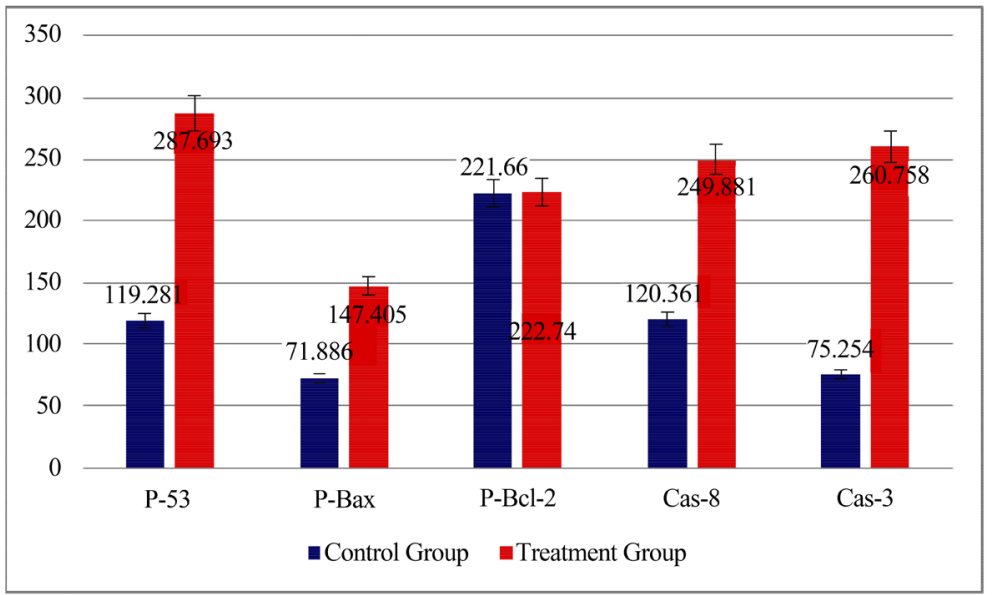

Figure 2. The contribution of the dependent variables in the control and experimental groups.

Table 3. Classification function coefficients. Fisher's Coefficients for p53, Bax, Bcl-2, Caspase-8 and Caspase-3.

\begin{tabular}{ccc}
\hline Dependent Variable & \multicolumn{2}{c}{ Group } \\
\hline P-53 & Control & Treatment \\
P-Bax & 119.281 & 287.693 \\
P-Bcl2 & 71.886 & 147.405 \\
Cas-8 & 221.660 & 222.740 \\
Cas-3 & 120.361 & 249.881 \\
(Constant) & 75.254 & 260.758 \\
\hline
\end{tabular}

Note: Fisher's linear discriminant functions. 
Table 4. The accuracy of the discriminant functions classification based on the classification results.

\begin{tabular}{|c|c|c|c|c|c|}
\hline & & \multirow{2}{*}{ Group } & \multicolumn{3}{|c|}{ Predicted Group Membership } \\
\hline & & & Control & Treatment & Total \\
\hline \multirow{4}{*}{ Original } & \multirow{2}{*}{ Count } & Control & 5 & 0 & 5 \\
\hline & & Treatment & 0 & 5 & 5 \\
\hline & \multirow{2}{*}{$\%$} & Control & 100.0 & 0.0 & 100.0 \\
\hline & & Treatment & 0.0 & 100.0 & 100.0 \\
\hline \multirow{4}{*}{ Cross-validated } & \multirow{2}{*}{ Count } & Treatment & 5 & 0 & 5 \\
\hline & & Treatment & 0 & 5 & 5 \\
\hline & \multirow{2}{*}{$\%$} & Control & 100.0 & 0.0 & 100.0 \\
\hline & & Treatment & 0.0 & 100.0 & 100.0 \\
\hline
\end{tabular}

It has been reported that EGCG can boost apoptotic index in human's epidermal carcinoma cells A431 (Kelly et al. [47]). According to Ahmad, et al. [48], apoptosis in human's colon adenocarcinoma HT-29 could be induced by EGCG. Apoptosis can also be triggered by theaflavin and in vivo EGCG. Either theaflavin or EGCG can inhibit cell proliferation and as a result improve apoptosis. This inhibition process significantly affects lungs carcinogenesis induced by $\mathrm{BP}$ in strain A mice (Banerjee et al. [14]). The current research suggest that an increase in the apoptotic index in the experimental group can be a result of the administration of the mahkota dewa polyphenols.

The results of the statistical analyses performed in this research indicated that polyphenols extracted from the mahkota dewa plants could inhibit lungs carcinogenesis in mice through cell proliferation and apoptotic mechanisms. Similarly, the correlation between Bax, Bcl-2, Cas-3 was also significant ( $\mathrm{p}=0.000$ ) and strong $(r=0.624 ; 0.754 ; 0.605)$. These figures, therefore, the increase of Bax protein as well as the decrease of Bcl-2 which in turn activates caspase- 3 in the apoptotic mechanism.

There was also a strong and significant relationship found between $\mathrm{p} 53$ and Bax, Cas- 8,9 and 3 proteins $(p=0.001 ; 0.000)$. Theories suggest that the activation of Bax protein by $\mathrm{p} 53$ will result in releasing c-cytochrome from caspase- 9 and end up activating caspase- 3 and caspase- 8 on the death receptor. Mahkota dewa polyphenols extracted from the have been proved able to activate p53 protein so that caspase- 8 is boosted and caspase- 3 is triggered.

The correlation between Bax and Bcl-2 was significant $(\mathrm{p}=0.000)$ and strong $(r=0.000)$. This finding suggest that the decreased Bcl-2 expression as an anti-apoptosis and the increased Bax expression as a pro-apoptosis lead to the release of c-cytochrome which initiates an assembly of Apaf-1 (Apoptotis protease-activating factor) and pro-caspase 9 to form an apoptosome. ATP is needed by Apaf- 1 to recruit procaspase 9 through the so-called CARD (caspase recruiting domain). Then, procaspase- 9 is autolitically broken down into active 
caspase 9 which can activate pro-caspase 3 and disintegrate substrates and apoptosis. This finding indicate that apoptosis induction by the mahkota dewa polyphenols is not determined by the level of Bcl-2 and Bax expressions only, but by the ratio of both (Chao and Korsmeyer [49]).

The correlation between caspase- 8 , caspase- 9 and caspase- 3 was significant ( $p$ $=0.000)$ and strong $(\mathrm{r}=0.744)$. These findings suggest that caspase- 8 , caspase- 9 and caspase- 3 play a significant role in inhibiting cell proliferation and inducing apoptosis. Therefore, the administration of the mahkota dewa polyphenols is effective to inhibit lungs carcinogenesis.

Based on the results of the discriminant function analysis, p53, Bax, Bcl-2, caspase- 8 and -3 played a major role in mice lungs carcinogenesis. However, caspase- 9 was reported to have no positive effect on the inhibition of the lungs carcinogenesis. Variable caspase- 9 was known to establish weak interactions with other dependent variables despite the result of the non-parametric analysis (Kruskal-Wallis followed by Mann-Whitney test). Caspase- 9 on mitochondrial pathways and Caspase- 8 on death receptor pathways are considered as an initiator that is responsible to activate downstream, caspase-3, -6 and -7 effectors (Viktorsson $\mathrm{K}$ and Lewensohn [8]). Caspase-9 and Caspase-8 interact with each other to execute Caspase-3 so that an apoptotic process could happen. The interaction between variables of this research indicates that the role of Caspase- 8 on the death receptor pathways is dominant in activating Caspase- 3 and inducing apoptosis.

The results of the discriminant functions analysis also suggested that the apoptotic mechanism was initiated by cell proliferation indicated in the increase of $\mathrm{p} 53$ and Bax proteins and the decrease of $\mathrm{Bcl}-2$ proteins that resulted in the permeability of mitochondria membrane. This process led to the release of c-cytochrome and the activation of Caspase-9, Caspase-8, and caspase- 3 so that apoptosis can be induced. Therefore, it can be concluded that the administration of the mahkota dewa polyphenols is effective in improving the functions of the dependent variables (p53, Bax, Bcl-2, Caspase-8 dan -3).

Overall, the results of this research suggest that polyphenols extracted from the mahkota dewa plants could act as a suppressor agent by inducing apoptosis. In addition, the administration of the polyphenols can transduce death signal either through death receptor or mitochondrial pathways. Even though it has not been proved which pathway is dominant, it can be assumed that there is a crosstalk relationship between those two pathways at different levels. The interaction between the two pathways, therefore, can activate caspase- 3 and induce apoptosis (Mohan et al. [39], Gupta [50]). In short, it can be said that the mahkota dewa polyphenols can perform an anti-cancer activity to inhibit lungs carcinogenesis the increase of p53, Bax, Bcl-2, caspase-8, caspase-9, and caspase- 3 .

Thus, it can be said that the mahkota dewa polyphenols have anti-cancer activity that can play a role in the process of inhibition of pulmonary carcinogenesis in experimental animals through the mechanism of inhibition of pulmonary 
carcinogenesis, increased protein 53, Bax protein and Bcl-2 and increased caspase- 8 , caspase- 9 and caspase- 3 .

\section{Conclusion}

The results of this study indicate that there is a relationship between apoptotic cell death mediated by death receptor (extrinsic) and mitochondria (intrinsic) through the administration of mahkota dewa polyphenols, it can be argued that mahkota dewa polyphenols can function in lung cancer chemoprevention in mice strain Balb/c.

\section{Acknowledgements}

Thanks to Dr. Totok Utari, Dr.Med.Sc, Sp.PA (K), teaching staff in the Anatomical Pathology Section of the Faculty of Medicine, Gadjah Mada University who have read the results of the research preparations during the research process. Dr. drg. Henry Setiawan, M.Sc, Epidemiology Section, Faculty of Public Health, Diponegoro University, and Dr. Hardian Permadi, M.Sc who helped in analyzing statistics. Prof. Dr. drh. Pudji Astuti, MP who has permitted and assisted the process of conducting experimental animal studies in the laboratory. Dr. Prijono Tirtoprodjo, Sp.PA (K), who allowed me to make preparations by painting H\&E, doing IHC pieces in the laboratory. Head of Anatomy Pathology Laboratory Regional General Hospital Dr. Sardjito Yogyakarta. Mr. Anif Usman, a technician at the Integrated Research and Testing Laboratory, Research Services Unit I (LPPT-Unit I) who is always loyal to help me do the fractionation and analysis of total polyphenols at the LPPT-Unit I Laboratory. Yunadir and Sumantri at the Anatomy Pathology Laboratory UGM and Mrs. Agustine Siswantono, technician at the Anatomy Pathology Laboratory Dr. Sardjito, who greatly assisted researchers in the review and painting of immunohistochemistry during the study.

\section{Conflicts of Interest}

The authors declare no conflicts of interest regarding the publication of this paper.

\section{References}

[1] Breuer, R.H.J., Postmus, P.E. and Smit, E.F. (2005) Molecular Pathology of NonSmall-Cell Lung Cancer. Respiration, 72, 313-330.

https://doi.org/10.1159/000085376

[2] Hanahan, D. and Weinberg, R.A. (2000) The Hallmark of Cancer. Cell, 100, 57-70. https://doi.org/10.1016/S0092-8674(00)81683-9

[3] Vousden, K.H. and Lu, X. (2002) Live or Let Die: The Cell's Response to p53. Nature Reviews Cancer, 2, 594-604. https://doi.org/10.1038/nrc864

[4] Fisher, D.E. (2004) Apoptosis in the Cancer Therapy: Crossing the Threshold. Cell, 78, 539-542. https://doi.org/10.1016/0092-8674(94)90518-5

[5] Sareen, D., Ginkel van, P.R., Takach, J.C., Mohiuddin, A., Darjatmoko, S.R., Albert, D.M. and Polans, A.S. (2006) Mitochondria as the Primary Target of Resveratrol- 
Induced Apoptosis in Human Retinoblastoma Cells. Investigative Ophthalmology \& Visual Science, 47, 3708-3716. https://doi.org/10.1167/iovs.06-0119

[6] Zimmermann, K.C., Bonzon, C. and Green, D.R. (2001) The Machinery of Programmed Cell Death. Pharmacology \& Therapeutics, 92, 57-70. https://doi.org/10.1016/S0163-7258(01)00159-0

[7] Pop, C., Timmer, J., Sperandio, S. and Salvesen, G.S. (2006) The Apoptosome Activates Caspase-9 by Dimerization. Molecular Cell, 22, 269-275. https://doi.org/10.1016/j.molcel.2006.03.009

[8] Viktorsson, K. and Lewensohn, R. (2007) Apoptotic Signaling Pathways in Lung Cancer. Journal of Thoracic Oncology, 2, 175-179. https://doi.org/10.1097/JTO.0b013e318031cd78

[9] Garrido, C., Galluzzi, L., Brunet, M., Puig, P.E., Didelot, C. and Kroemer, G. (2006) Mechanisms of Cytochrome c Release from Mitochondria. Cell Death Different, 13, 1423-1433. https://doi.org/10.1038/sj.cdd.4401950

[10] Owen-Schaub, L.B., Zhang, W., Cusack, J.C., Angelo, L.S., Santee, S.M., Fujiwara, T., Roth, J.A., Deisseroth, A.B., Zhang, W.-W., Kruzel, E. and Radinsky, R. (1995) Wild-Type p53 and a Temperature Sensitive Mutant Induce FasrAPO-1 Expression. Molecular and Cellular Biology, 15, 3032-3040.

https://doi.org/10.1128/MCB.15.6.3032

[11] Sreedhar, A.S. and Csermely, P. (2004) Heat Shock Proteins in the Regulation of Apoptosis: New Strategies in Tumor Therapy: A Comprehensive Review. Pharmacology \& Therapeutics, 101, 227-257. https://doi.org/10.1016/j.pharmthera.2003.11.004

[12] Crighton, D. and Ryan, K.M. (2004) Splicing DNA-Damage Responses to Tumor Cell Death. Biochimica et Biophysica Acta, 1705, 3-15. https://doi.org/10.1016/j.bbcan.2004.09.001

[13] Rousselot, N.V. and Garnero, P. (2007) Biochemical Markers in Oncology. Part I: Molecular Basis. Cancer Treatment Reviews, 33, 230-283. https://doi.org/10.1016/j.ctrv.2007.01.008

[14] Banerjee, S., Manna, S., Saha, P., Panda, C.K. and Das, S. (2005) Black Tea Polyphenols Suppress Cell Proliferation and Induce Apoptosis during Benzo(a)pyreneInduced Lung Carcinogenesis. European Journal of Cancer Prevention, 14, 215-221. https://doi.org/10.1097/00008469-200506000-00004

[15] Kintono and Pihie, H.A.L. (2009) Fragmentation Analysis Using Agarose Gel Electrophoresis Technique in Apoptotic Hela Cancer Cell Culture. Proceeding of the National Seminar TOI-KKN, Yogyakarta, 13-14 Mei 2009.

[16] Banerjee, S., Panda, C.K. and Das, S. (2006) Clove, a Potential Chemopreventive Agent for Lung Cancer. Carcinogenesis, 27, 1645-1654. https://doi.org/10.1093/carcin/bgi372

[17] Manson, M. (2003) Cancer Prevention the Potential for Diet to Modulate Molecular Signaling. Trends in Molecular Medicine, 9, 11-18. https://doi.org/10.1016/S1471-4914(02)00002-3

[18] Surh, Y.J. (2003) Cancer Chemoprevention with Dietary Phytochemicals. Nature Reviews Cancer, 3, 768-780. https://doi.org/10.1038/nrc1189

[19] Soeksmanto, A. (2006) Effect of Butanol Extract of the Mahkota Dewa (Phaleria macrocarpa [Scheff.] Boerl.) on the Kidney Tissue of Mice (Mus musculus). Biodiversity, 7, 278-281. https://doi.org/10.13057/biodiv/d070317

[20] Soeksmanto, A. (2006) Effect of Butanol Extract of the Mahkota Dewa (Phaleria macrocarpa [Scheff.] Boerl.) on the Kidney Heart of Mice (Mus musculus). Biodi- 
versity, 7, 340-343. https://doi.org/10.13057/biodiv/d070408

[21] Finley, J.W. (2005) Proposed Criteria for Assessing the Efficacy of Cancer Reduction by Plant Foods Enriched in Carotenoids, Glucosinolates, Polyphenols and Seleno Compounds. Annals of Botany, 95, 1075-1096. https://doi.org/10.1093/aob/mci123

[22] Ross, J.A. and Kasum, C.M. (2002) Dietary Flavonoids: Bioavailability, Metabolic Effects, and Safety. Annual Reviews in Nutrition, 22, 19-34. https://doi.org/10.1146/annurev.nutr.22.111401.144957

[23] Scalbert, A., Manach, C., Morand, C., Remesy, C. and Jimenez, L. (2005) Dietary Polyphenols and the Prevention of Diseases. Critical Reviews in Food Science and Nutrition, 45, 287-306. https://doi.org/10.1080/1040869059096

[24] Giovannelli, L., Testa, G., De Filippo, C., Cheynier, V., Clifford, M.N. and Dolara, P. (2000) Effect of Complex Polyphenols and Tannins from Red Wine on DNA Oxidative Damage of Rat Colon Mucosa in Vivo. European Journal of Nutrition, 39, 207-212. https://doi.org/10.1007/s003940070013

[25] Lisdawati, V. (2002) Mahkota Dewa (Phaleria macrocrapa (Scheff.) Boerl.), Toxicity, Antioxidant Effects and Anticancer Effects Based on Pharmacological Screening Tests. Indonesian Journal of Medical, 9, 34-39.

[26] Watuguly, T.W., Yotopranoto, S. and Subekti, S. (2005) Bioinsecticide Test on the Extract of Mahkota Dewa (Phaleria papuana Warb.) Seed on the Mortality of Aedes aegypti Linn Larvae Stage in the Laboratory. Indonesian Journal of Tropical Medicine, 17, 33-46.

[27] Watuguly, T.W., Yotopranoto, S. and Subekti, S. (2006) Bioinsecticide Test on the Extract of Mahkota Dewa (Phaleria papuana Warb.) Seed on the Mortality of Aedes aegypti Linn Adult Stage in the Laboratory. Indonesian Journal of Tropical Medicine, 17, 11-20.

[28] Faried, A., Kurnia, D., Faried, L.S., Usman, N., Miyazaki, T., Kato, H. and Kuwano, H. (2007) Anticancer Effects of Gallic Acid Isolated from Indonesian Herbal Medicine, Phaleria macrocarpa (Scheff.) Boerl. on Human Cancer Cell Lines. International Journal of Oncology, 30, 605-613. https://doi.org/10.3892/ijo.30.3.605

[29] Sutiono, A.B., Faried, A., Arifin, M.Z. and Wiridisastra, O.T. (2008) Herbal Medicine Isolation, Phaleria macrocarpa (Scheff.) Boerl for Primary Glioblastoma Multiforme Cells. Annals of Epidemiology, 18, 718-722. https://doi.org/10.1016/j.annepidem.2008.08.037

[30] Shahrzad, S. and Bitsch, I. (2008) Determination of Gallic Acid and Its Metabolites in Human Plasma Dan Urin by High-Performance Liquid Chromatography. Journal of Chromatography B: Biomedical Sciences and Applications, 705, 87-95. https://doi.org/10.1016/S0378-4347(97)00487-8

[31] Budijitno, S., Issakh, B., Handojo, D., Pudjonarko, D. and Riwanto, I. (2007) Pengaruh ekstrak mahkota dewa (Phaleria macrocarpa) terhadap skor ekspresi perforin CTL dan sel-NK serta indeks apoptosis pada adenokarsinoma mamma mencit $\mathrm{C} 3 \mathrm{H}$. Media Medika Indonesiana, 42, 13-20.

[32] Rahmawati, E., Dewoto, H.R. and Wuyung, P.E. (2006) Anticancer Activity Study of Ethanol Extract of Mahkota Dewa Fruit Pulp (Phaleria macrocarpa [Scheff.] Boerl.) in $\mathrm{C} 3 \mathrm{H}$ Mouse Mammary Tumor Induced by Transplantation. Medical Journal of Indonesia, 15, 217-222. https://doi.org/10.13181/mji.v15i4.237

[33] Sugiwati, S., Kardono, L.B.S. and Bintang, M. (2006) $\alpha$-Glucosidase Inhibitory Activity and Hypoglycemic Effect of Phaleria macrocarpa [Scheff.] Boerl. Fruit Pericarp Extracts by Oral Administration to Rats. Journal of Applied Sciences, 6, 2312 
2316. https://doi.org/10.3923/jas.2006.2312.2316

[34] Frei, B. and Higdon, J.V. (2003) Antioxidant Activity of Tea Polyphenols in Vivo: Evidence from Animal Studies. Journal of Nutrition, 133, 3275S-3284S. https://doi.org/10.1093/jn/133.10.3275S

[35] Giovannini, C., Scazzocchio, B., Vari, R., Santangelo, C., Archivio, D.M. and Masella, R. (2007) Apoptosis in Cancer and Artherosclerosis: Poliphenol Activities. Annali delP Istituto Superiore di Sanità, 43, 406-416.

[36] Portney, G., Leslie, P. and Mary, P.W. (1993) Foundations of Clinical Research Application to Practice. Appleton \& Lange, Norwalk, 148-152.

[37] Gross, P.L. and Mary, P.W. (1993) Foundations of Clinical Research Application to Practice. Appleton \& Lange, Norwalk, 148-152.

[38] Campbell, D.T. and Stanley, J.C. (1996) The Post Test-Only Control Group Design. In: Experimental and Quasi-Experimental Designs for Research, Rand McNally College Publishing Co., Chicago, 25-31.

[39] Mohan, K.P.V.C., Devaraj, H., Prathiba, D., Hara, Y. and Nagini, S. (2006) Antiproliferative and Apoptosis Inducing Effect of Lactoferrin and Black Tea Polyphenol Combination on Hamster Buccal Pouch Carcinogenesis. Biochimica et Biophysica Acta, 1760, 1536-1544. https://doi.org/10.1016/j.bbagen.2006.06.009

[40] Letchoumy, P.V., Mohan, K.V.P.C., Prathiba, D., Hara, Y. and Siddavaram, N. (2007) Comparative Evaluation of Antiproliferative, Antiangiogenic and Apoptosis Inducing Potential of Black Tea Polyphenols in the Hamster Buccal Pouch Carcinogenesis Model. Journal of Carcinogenesis, 6, 1-13. https://doi.org/10.1186/1477-3163-6-19

[41] Watuguly, T.W., Tjahjono, Kaihena, M. and Wael, Sy. (2012) Induction of Mahkota Dewa Polyphenols in Apoptosis of Lung Cancer Cells Balb/c Strain Mice through Up-Regulation of Bax and Down-Regulation of Bcl-2. Media Medika Indonesiana, 46, 97-99. https://ejournal.undip.ac.id/index.php/mmi/article/view/4210

[42] Watuguly, T.W., Indranila, K.S., Papilaya, P.M. and Dharmana, E. (2013) The Role of Mahkota Dewa Polyphenols Dissolve Cell Proliferation and Induce Apoptosis in Benzo (a) Pyrene (Ba) Induced Strain Mice. Media Medika Indonesiana, 47, 112 116. https://ejournal.undip.ac.id/index.php/mmi/article/view/11375

[43] Watuguly, T.W. (2018) Chemoprevention of Lung Carcinogenesis in Strain Balb/c Mice with Polyphenols of Mahkota Dewa (Phaleria macrocarpa) from Indonesian Herbal. International Journal of Advanced Research, 6, 580-590. https://doi.org/10.21474/IJAR01/7069

[44] Watuguly, T.W. (2018) Biomolecular Aspect of Apoptosis Pathway: Caspase-8 and Caspase-9 on Polifenol Exposure of Phaleria macrocarpa (Scheff.) Boerl on Mice Balb/c. Universal Journal of Public Health, 6, 173-180. https://doi.org/10.13189/ujph.2018.060402

[45] Indranila, K.S., Watuguly, T.W. and Judiono, C.L. (2016) Polyphenol Compounds of Mahkota Dewa Up-Regulation Caspase-3 and Apoptosis Index in Balb/c Strain Mice. Functional Food in Health and Disease, 6, 206-218. https://doi.org/10.31989/ffhd.v6i4.243

[46] Bonner, A.E., Lemon, W.J., Devereux, T.R., Lubet, R.A. and You, M. (2004) Molecular Profiling of Mouse Lung Tumors: Association with Tumor Progression, Lung Development and Human Lung Adenocarcinoma. Oncogene, 23, 1166-1176. https://doi.org/10.1038/sj.onc.1207234

[47] Kelly, K.J., Sandoval, R.M., Dunn, K.W., Molitoris, B.A. and Dagher, P.C. (2003) A Novel Method to Determine Specificity and Sensitivity of the TUNEL Reaction in 
the Quantitation of Apoptosis. American Journal of Physiology: Cell Physiology, 284, C1309-C1318. https://doi.org/10.1152/ajpcell.00353.2002

[48] Ahmad, N., Adhami, V.M., Afaq, F., Feyes, D.K. and Mukhtar, H. (2001) Resveratrol Causes WAF-1/p21-Mediated G1-Phase Arrest of Cell Cycle and Induction of Apoptosis in Human Epidermoid Carcinoma A431 Cells. Clinical Cancer Research, 7, 1466-473. https://www.ncbi.nlm.nih.gov/pubmed/11350919

[49] Chao, D.T. and Korsmeyer, S.J. (1998) Bcl-2 Family: Regulator of Cell Death. Annual Review of Immunology, 16, 395-419.

https://doi.org/10.1146/annurev.immunol.16.1.395

[50] Gupta, S. (2003) Molecular Signaling in Death Receptor and Mitochondria Pathway of Apoptosis (Review). International Journal of Oncology, 22, 15-20.

https://www.ncbi.nlm.nih.gov/pubmed/12469180 